Volume 8, Issue 1, 249 - 255.

ISSN: 2165-8714

http://www.eu-jer.com/

\title{
Self-Efficacy and the Use of Compensatory Strategies: A Study on EFL Learners
}

\author{
Aynur Kesen Mutlu \\ Istanbul Medipol University, TURKEY
}

\author{
Mehdi Solhi Andarab \\ Istanbul Medipol University, TURKEY
}

\author{
Cemil Gokhan Karacan * \\ Istanbul Medipol University, TURKEY
}

Received: September 4, 2018 - Revised: December 23, $2018 \cdot$ Accepted: January 7, 2019

\begin{abstract}
This study aimed to explore the relationship between Turkish English as a Foreign Language (EFL) learners' self-efficacy level and their opinion regarding their use of compensatory strategies (CSs). The study further searched into the most and the least frequently used CSs by Turkish EFL learners. The participants of the study were fifty university students enrolled in the department of English Language Teaching at a private university in Istanbul, Turkey. Results indicated that the level of self-efficacy among Turkish learners of EFL was high. The top two most frequently used CSs by the learners were concluded to be the use of non-verbal signals (i.e., mime, gesture, facial expression) and circumlocution (i.e., describing an object or idea with a definition). In addition, the two least frequently used strategies were word coinage (i.e., creating a non-existent second language word based on a supposed rule) and avoidance (i.e., avoiding a topic, concept, grammatical construction, or phonological element that poses difficulty). The findings also revealed that the participants' strategy use was not related to their degree of self-efficacy.
\end{abstract}

Keywords: Compensatory strategies, EFL learners, self-efficacy

To cite this article: Kesen Mutlu, A., Solhi Andarab, M., \& Karacan, C. G. (2019). Self-efficacy and the use of compensatory strategies: A study on EFL learners. European Journal of Educational Research, 8(1), 249-255. doi: 10.12973/eu-jer.8.1.249

\section{Introduction}

Language learning is affected by a variety of factors such as motivation, anxiety, and learner beliefs and characteristics. Self-efficacy, as a learner characteristic, refers to learner's "judgments of their capabilities to organize and execute courses of action required to attain designated types of performances" (Bandura, 1986, p. 391). Gahungu (2007) argues that self-efficacy is not a set of skills a person possesses to accomplish a task, but judgments of what they can do with these skills. Perception of self-efficacy positively affects people's goals, efforts devoted and willingness to persevere in the case of failure (Bandura, 1986). Direct and indirect effects of students' self-efficacy on their achievements have been taken into close scrutiny by various researchers at different times (Bouffard-Bouchard, 1990; Carmichael \& Taylor, 2005; Schunk, 2003).

Academic self-efficacy has been found to be a strong predictor of academic achievement (Klomegah, 2007; Valcke \& Cai, 2009) which supports Bandura's (1997) statement regarding the influence of self-efficacy on academic performance. Moreover, Whang and Hancock (1994), Eaton and Dembo (1997) and Margolis and Mccabe (2006) have correspondingly investigated the relationship between academic self-efficacy and performance in relation to cultures, and according to the findings, self-efficacy was reported to have an effect on the achievement of the learners.

The influence of students' self-efficacy on motivation and learning has been explored by several researchers, as well (Bouffard-Bouchard, 1990; Lent, Brown, \& Heckett, 2002; Linnenbrink \& Pintrich, 2003; Margolis \& Mccabe, 2006; Schunk, 1991; Zimmerman, Bandura, \& Martinez-Pons, 1992). Findings of these studies suggest that self-efficacy affects motivation and cognition along with students' increased task-related performances, use of cognitive, meta-cognitive and CSs. In the context of foreign language learning, students' self-efficacy and the factors that affect learners' selfefficacy have been explored in many studies since it is believed that self-efficacy "is a strong predictor of performance in different language skills and tasks" (Raoofi, Hoon Tan, \& Heng Chan, 2012, p. 60). Relationship of self-efficacy with English learning and proficiency has been widely investigated, as well (e.g., Brady-Amoon \& Fuertes, 2011; Kim, Wang, Ahn, \& Bong, 2015; Lin \& Wang, 2010; Rahimi \& Abedini, 2009). Besides, self-efficacy has been researched in relation to four language skills, namely, listening (Chen, 2007; Graham, 2011; Rahimi \& Abedini, 2009), speaking (Liu, 2013), writing (Hossesini, Fatemi \& Vahidnia, 2013; Huang \& Shanmao, 1996), and reading skills (Ghonsooly \& Elahi, 2011; Kargar \& Zamanian, 2014).

\footnotetext{
* Corresponding author:

Cemil Gokhan Karacan, English Language Teaching Department, School of Education, Istanbul Medipol University, Istanbul, Turkey.

$\bowtie$ cgkaracan@medipol.edu.tr
} 
Apart from self-efficacy as a predictor of the learners' performance, learning strategies have been a subject that has attracted the researchers' attention over the last years (Demirel, 2012; Green \& Oxford, 1995; Rababah \& Bulut, 2007; Taheri \& Davoudi, 2016; Yilmaz, 2010). In fact, language learners perform various learning strategies during their language production. Four decades ago, it was suggested that language learning strategies included "any sets of operations, steps, plan, routines used by the learner to facilitate the obtaining, storage, retrieval and use of information" (Rubin \& Wenden, 1978, p.19). In the literature, over the last years, the concept of language learning strategies has been generally divided into two categories. O'Malley and Chamot (1990), and Oxford (1990) classify two categories of language strategies that are direct and indirect. While indirect strategies contain metacognitive, affective and social factors which are not directly related with the target language, direct strategies are associated with mental processing of the language along with memory, cognitive strategies and CSs which are defined as the strategies "needed to overcome any gaps in knowledge of the language" (Oxford, 1990, p. 71). Language learners try to counterbalance their restricted linguistic and non-linguistic knowledge in the target language by employing CSs which might enhance their communicative competence. A concise definition has been suggested by Rababah (2004) indicating that "(l)anguage learners attempt to solve their communication problems when they lack adequate resources in the target language by resorting to CSs. Most researchers agree that CSs are used to bridge the gap that exists between the non-native speakers' linguistic competence in the target language and their communicative needs" (p.148).

As Brown (2014) states, CSs pertains to output, how we productively express meaning, and how we deliver messages to others. The concept of CSs refers to use of a couple of strategic options designed to overcome self-perceived weaknesses, such as using avoidance, circumlocution, approximation, word coinage, non-verbal signals, prefabricated patterns, code switching, appeal to authority, and keeping the floor (Brown, 2014). Use of CSs is not exclusive to either native or non-native speakers but non-speakers may employ them more frequently because of their insufficient competence in the target language.

Language learning strategies have been extensively explored in foreign language learning context. However, CSs have not been thoroughly touched upon. To give an example, studies investigating CSs have dealt generally with defining, identifying and classifying the CSs, while the rest has concerned with the effect of different variables on CSs use and teachability issues (Bialystok, 1983; Færch \& Kasper 1983; Taheri \& Davoudi, 2016; Tarone, 1977). Studies conducted by Yilmaz (2010) and Demirel (2012) revealed that CSs were the most frequent ones when compared to learning strategies. Green and Oxford (1995) found a significant relationship between proficiency and the compensation category of strategies. Margolis' (2001) study revealed that learners employed various strategies especially asking for more information or confirmation to compensate for deficiencies in listening and speaking skills of their target language. Rababah \& Bulut (2007) probed into CSs used in the oral discourse and results showed that students used a wide range of CSs in oral production. While paraphrasing was used as the most frequent CS, coinage and asking for repetition were the least frequent ones. Liskin-Gasparro (1996) analyzed the use of CSs, primarily circumlocution, and found out that advanced speakers rely more on a range of language learning strategies when compared to upperintermediate speakers of that target language.

\section{The significance of the study}

It is known that self-efficacious learners have many advantages in foreign language learning including risk-taking, taking a more active role in the learning process, and achieving their goals. Likewise, the use of CSs helps learners to improve their knowledge and accomplish language tasks throughout the learning process. Both self-efficacy and CSs have been investigated in many studies by various scholars in the field; however, the related literature does not include any studies investigating the relationship between learners' self-efficacy level and their use of CSs. In this respect, there seems to be a need in the Turkish context to search into the question whether learners' level of self-efficacy and their use of CSs are related to each other. For this reason, the current study aims to contribute to the field by providing a case in the Turkish context.

\section{Methodology}

\section{Research Goal}

The purpose of this study was to search into the relationship between Turkish EFL learners' self-efficacy level and their use of CSs in Oral Communication Skills Course. The study aims to shed light onto the question wheth er learners' selfefficacy could be regarded as a predictor of the use of CSs by the EFL learners. For this very specific purpose, the following research questions were under investigation in this study:

RQ1: What is the self-efficacy level of Turkish EFL students?

RQ2: What are the most frequently used compensatory strategies by Turkish EFL learners?

RQ3: What are the least frequently used compensatory strategies by Turkish EFL learners?

RQ4: Is there a significant relationship between Turkish EFL learners' self-efficacy level and their use of compensatory strategies? 
Research design

In the current study, quantitative research design was used, and the data collected through self-efficacy scale and compensatory strategies scale were analyzed through descriptive statistics.

\section{Participants}

The students participating in this study were 50 EFL (14 male and 36 female) learners studying in the ELT department of a private university in Turkey. They were mostly ranging from 18 to 22 years old. The participants were all volunteers. When data were collected for the current study, the participants had completed Oral Communication Skills 1 and Advanced Reading and Writing 1 courses offered in the department.

\section{Instruments}

Two questionnaires were used to elicit responses from the participants. The first questionnaire comprised of nine compensatory strategies, namely, avoidance (CS1), circumlocution (CS2), approximation (CS3), word coinage (CS4), non-verbal signals (CS5), prefabricated patterns (CS6), code switching (CS7), appeal to authority (CS8), and keeping the floor (CS9). All the strategies listed in the questionnaire were based on Brown's (2014) classification of CSs. For each of the items, the participants were expected to circle the response that best characterizes what they do to compensate when their language production breaks down. The responses ranged from strongly disagree to totally agree. The second questionnaire comprised of 28 items which were designed to measure speaking skills self-efficacy of the learners. the items in the scale were based on a 5-point Likert scale. The questionnaire was adapted by Asakereh and Dehgannezhad (2015). All the participants attended a short session in which all the items in the questionnaires were clarified by the researchers.

\section{Findings / Results}

RQ1: What is the self-efficacy level of Turkish EFL students?

The first research question investigated the self-efficacy level of Turkish EFL students participating in this study. With 28 questions for self-efficacy the maximum value for this variable will amount to 140 while the minimum value will be equal to 28. If we divide the difference between the lowest and the highest values for self-efficacy (112) by 3, we will have 37.33 which can be rounded to 37 . In line with this approach, we can conclude that students falling below 65 (28 + 37 ) will belong to the low self-efficacy group. Students whose scores fall between 66 and 103 will belong to the mid self-efficacy group; and finally, students obtaining scores above 103 will constitute the high self-efficacy group. With respect to the mean value of self-efficacy calculated for the students participating in this study, as represented in Table 1, the level of self-efficacy among the Turkish learners of English as a foreign language is high but very close to the borderline between the mid and high levels. It needs to be pointed out here that a few cells with missing values in the data were filled with 3 or the middle number on the scale.

Table 1. Mean Value of Turkish EFL Learners' Self-efficacy

\begin{tabular}{llllll}
\hline & $\mathrm{N}$ & Minimum & Maximum & Mean & Std. Deviation \\
\hline totals & 50 & 61.00 & 136.00 & 104.1200 & 15.04773 \\
Valid N (listwise) & 50 & & & & \\
\hline
\end{tabular}

RQ2: What are the most frequently used compensatory strategies by Turkish EFL learners?

RQ3: What are the least frequently used compensatory strategies by Turkish EFL learners?

The second and the third research questions targeted the most and the least frequently used CSs by the Turkish EFL learners. Table 2 represents the CSs from the most frequently used to the least frequently used in a descending order. The top two most frequently used strategies by the Turkish EFL learners, therefore, are CS5 and CS2. The two least frequently used strategies, on the other hand, are CS4 and CS1. 
Table 2. Compensatory Strategies in the Order of Frequency of Use

\begin{tabular}{lcccccc}
\hline & N & Minimum & Maximum & Sum & Mean & Std. Deviation \\
\hline CS5 & 50 & 2.00 & 5.00 & 195.00 & 3.9000 & .86307 \\
CS2 & 50 & 2.00 & 5.00 & 195.00 & 3.9000 & .81441 \\
CS9 & 50 & 1.00 & 5.00 & 194.00 & 3.8800 & .93982 \\
CS3 & 50 & 2.00 & 5.00 & 187.00 & 3.7400 & 1.02639 \\
CS8 & 50 & 1.00 & 5.00 & 169.00 & 3.3800 & .96658 \\
CS6 & 50 & 2.00 & 5.00 & 166.00 & 3.3200 & .89077 \\
CS7 & 50 & 1.00 & 5.00 & 166.00 & 3.3200 & 1.03884 \\
CS1 & 50 & 2.00 & 5.00 & 162.00 & 3.2400 & 1.00122 \\
CS4 & 50 & 2.00 & 5.00 & 160.00 & 3.2000 & .94761 \\
Valid N (listwise) & 50 & & & & & \\
\hline
\end{tabular}

RQ4: Is there a significant relationship between Turkish EFL learners' self-efficacy level and their use of compensatory strategies?

To address the fourth research question, we need to calculate the respondents' overall self-efficacy scores and correlate the set of calculated scores with the set of scores for each of the CSs. Table 3 shows the results of these correlations.

Table 3. Correlations Between CSs and Total SE

\begin{tabular}{|c|c|c|}
\hline & & Total SE \\
\hline \multirow[t]{3}{*}{ CS1 } & Pearson Correlation & .144 \\
\hline & Sig. (2-tailed) & .317 \\
\hline & $\mathrm{N}$ & 50 \\
\hline \multirow[t]{3}{*}{$\mathrm{CS} 2$} & Pearson Correlation & .262 \\
\hline & Sig. (2-tailed) & .066 \\
\hline & $\mathrm{N}$ & 50 \\
\hline \multirow[t]{3}{*}{ CS3 } & Pearson Correlation & .258 \\
\hline & Sig. (2-tailed) & .070 \\
\hline & $\mathrm{N}$ & 50 \\
\hline \multirow[t]{3}{*}{$\mathrm{CS} 4$} & Pearson Correlation & .171 \\
\hline & Sig. (2-tailed) & .234 \\
\hline & $\mathrm{N}$ & 50 \\
\hline \multirow[t]{3}{*}{ CS5 } & Pearson Correlation & $.362^{* *}$ \\
\hline & Sig. (2-tailed) & .010 \\
\hline & $\mathrm{N}$ & 50 \\
\hline \multirow[t]{3}{*}{ CS6 } & Pearson Correlation & .113 \\
\hline & Sig. (2-tailed) & .435 \\
\hline & $\mathrm{N}$ & 50 \\
\hline \multirow[t]{3}{*}{ CS7 } & Pearson Correlation & -.046 \\
\hline & Sig. (2-tailed) & .753 \\
\hline & $\mathrm{N}$ & 50 \\
\hline \multirow[t]{3}{*}{ CS8 } & Pearson Correlation & .154 \\
\hline & Sig. (2-tailed) & .286 \\
\hline & $\mathrm{N}$ & 50 \\
\hline \multirow[t]{3}{*}{ CS9 } & Pearson Correlation & .112 \\
\hline & Sig. (2-tailed) & .438 \\
\hline & $\mathrm{N}$ & 50 \\
\hline \multirow[t]{3}{*}{ totalSE } & Pearson Correlation & 1 \\
\hline & Sig. (2-tailed) & \\
\hline & $\mathrm{N}$ & 50 \\
\hline
\end{tabular}

Evidently, there is only one significant correlation coefficient among all of the correlation coefficients calculated in table 3 and it is between the scores for compensatory strategy number 5 and the total scores for self-efficacy. However, even this coefficient cannot be considered to be meaningful as to interpret correlation coefficients we have to square them which in this case will yield a very small and negligible value. Therefore, we can conclude with almost absolute certainty that the respondents' strategy use is not related to their degree of self-confidence. 


\section{Discussion and Conclusion}

How the learner can compensate for weaknesses and avoid various pitfalls while interacting in English underlines the significance of CSs in productive skills. Results indicated that non-verbal signals and circumlocution were the most frequently used, while word coinage and avoidance turned out to be the least frequently used CSs among the Turkish EFL learners participating in the current study. Instead of avoiding a pitfall and creating a new terminology in English, the Turkish participants mostly preferred to define and use of a large number of words to express their idea, or to use gestures and body movements while interacting in English.

Actually, the idea of measurement of strategies use has been a controversial issue. How adequate self-reports are for identifying strategy use in the classroom is a type of question that is likely to be asked (Brown, 2015). Some scholars even believe that the participants may not even understand the strategies named in the questionnaire or fail to remember the strategies they have used (White, Schramm, \& Chamot, 2007). Here familiarizing the students with different types of strategies and training them carry a significant importance. In this study, before administering the questionnaire on CSs, successful CSs and different types of them were explained to the students in a couple of sessions. Creating strategy awareness in the learners can be achieved by acquainting them with their own preferences in the situations which they need to rely on the CSs. The results also indicated that there is only one slightly significant correlation coefficient between the scores for non-verbal CS and the total scores for self-efficacy. Therefore, non-verbal signals that were one of the most frequently used types of CSs have correlation coefficient with the self-efficacy of the participants. Considering all other CS use of the participants in this study, it can be clearly said that they are not related to their degree of self-efficacy.

\section{Suggestions for further research}

It might be noteworthy to indicate that the current study is limited to the use of questionnaire as the research instrument. For this reason, more in-depth studies utilizing various instruments such as semi-structured interviews or learner's essays might contribute to developing a better insight into learners' self-efficacy and their use of CSs in the language classroom. The age and gender of the participants of the learners as a determining factor in preferring different types of CSs also appear to be fruitful avenues for future research.

\section{Implications of the study}

It is believed that learners' self-efficacy as well as the use of CSs are vital for learners' success. This study reported that the level of self-efficacy among Turkish learners of EFL is high but very close to the borderline between the mid and high levels. The study also revealed that there is only one slightly significant correlation coefficient between the scores for non-verbal CS and the total scores for self-efficacy. On the basis of this small-scale study, it should be stated that investigating language learners' self-efficacy and their use of CSs should be within the responsibility of language teachers as such an approach would help learners become aware of themselves as language learners and take the responsibility for their own learning and progress throughout language learning process.

\section{References}

Bandura, A. (1995). Social foundations of thought and action: A social cognitive theory. Englewood Cliffs, NJ: Prenctice Hall.

Basaran, S., \& Cabaroglu, N. (2014). The effect of language learning podcasts on English self-efficacy. International Journal of Language Academy, 2(2), 48-69.

Borton, W. M. (1991, April). Empowering teachers and students in a restructuring school: A teacher efficacy interaction model and the effect on reading outcomes. Paper presented at the annual meeting of the American Educational Research Association, Chicago. (ERIC Document Reproduction Service No. ED 335 341)

Bouffard-Bouchard, T. (1990). Influence of self-efficacy on performance in a cognitive task. Journal of Social Psychology, $130(3), 353-363$.

Bouffard-Bouchard, T., Parent, S., \& Larivée, S. (1991). Influence of self-efficacy on self-regulation and performance among junior and senior high-school age students. International Journal of Behavioral Development, 14(2), 153164.

Brady-Amoon, P., \& Fuertes, J. N. (2011). Self-efficacy, self-rated abilities, adjustment, and academic performance. Journal of Counseling \& Development, 89(4), 431-438.

Brookhart, S. M., Walsh, J. M., \& Zientarski, W. A. (2006). The dynamics of motivation and effort for classroom assessments in middle school science and social studies. Applied Measurement in Education, 19(2), 151-184.

Brown, H. D. (2014). Principles of Language Learning and Teaching (6th ed.). New York, NY: Pearson Education. 
Caprara, G. V., Barbaranelli, C., Steca, P., \& Malone, P. S. (2006). Teachers' self-efficacy beliefs as determinants of job satisfaction and students' academic achievement: A study at the school level. Journal of School Psychology, 44(6), 473-490.

Carmichael, C., \& Taylor, J. A. (2005). Analysis of student beliefs in a tertiary preparatory mathematics course. International Journal of Mathematical Education in Science and Technology, 36(7), 713-719.

Chen, H. Y. (2017, February 5). The relationship between EFL learners' self-efficacy beliefs and English performance. Retrieved from http://purl.flvc.org/fsu/fd/FSU_migr_etd-3846

Demirel, M. (2012). Language learning strategies of undergraduate students. Hacettepe University Journal of Education, 43, 141-153.

Ferla, J., Valcke, M., \& Cai, Y. (2009). Academic self-efficacy and academic self-concept: Reconsidering structural relationships. Learning and Individual Differences, 19(4), 499-505.

Gahungu, N. O. (2018, May 27). The relationships among strategy use, self-efficacy, and language ability in foreign language learners (Doctoral dissertation). Retrieved from_https://nau.edu/COE/.../Gahungu_Dissertation_PDF

Ghonsooly, B. \& Elahi, M. (2011). Learners self-efficacy in reading and its relation to foreign language reading anxiety and reading achievement. Journal of English Language Teaching and Learning, 53(127), 45-67.

Ghonsooly, B., Elahi, M., \& Golparvar, S. E. (2012). General English university students' self-efficacy and their achievement. Iranian EFL Journal, 8(3), 153-173.

Graham, S. (2011). Self-efficacy and academic listening. Journal of English for Academic Purposes, 10(2), 113-117.

Green, J. M., \& Oxford, R. (1995). A closer look at learning strategies, L2 proficiency, and gender. TESOL quarterly, 29(2), 261-297.

Hosseini Fatemi, A., \& Vahidnia, F. (2013). An investigation into Iranian EFL learners' level of writing self-efficacy. Theory and Practice in Language Studies, 3(9), 1698-1704.

Huang, S. C., \& Chang, S. F. (1996). Self-Efficacy of English as a Second Language Learner: An Example of Four Learners. (ERIC Document Reproduction Service No. ED396536).

Kargar, M., \& Zamanian, M. (2014). The relationship between self-efficacy and reading comprehension strategies used by Iranian male and female EFL learners. International Journal of Language Learning and Applied Linguistics World, $7(2), 313-325$.

Kim, D. H., Wang, C., Ahn, H. S., \& Bong, M. (2015). English language learners' self-efficacy profiles and relationship with self-regulated learning strategies. Learning and Individual Differences, 38, 136-142.

Klomegah, R. Y. (2007). Predictors of academic performance of university students: An application of the goal efficacy model. College Student Journal, 41(2), 407-415.

Lent, R.W., Brown, S.D., \& Hackett, G. (2002). Social cognitive career theory. In D. Brown, L. Brooks, and Associates (Eds.), Career choice and development (pp. 255-311).San Francisco, CA: Jossey-Bass.

Lin, Y., \& Wang, C. (2010). An empirical study of reading self-efficacy and the use of reading strategies in the Chinese EFL context. The Asian EFL Journal Quarterly, 12, 144-162.

Linnenbrink, E. A., \& Pintrich, P. R. (2003). The role of self-efficacy beliefs in student engagement and learning in the classroom. Reading and Writing Quarterly: Overcoming Learning Difficulties, 19(2), 119-137.

Liskin-Gasparro, J. E. (1996). Circumlocution, communication strategies, and the ACTFL proficiency guidelines: An analysis of student discourse. Foreign Language Annals, 2(3), 317-330.

Liu, M. (2013). English bar as a venue to boost students' speaking self-efficacy at the tertiary level. English Language Teaching, 6(12), 22-37.

Margolis, H., \& McCabe, P. P. (2006). Improving self-efficacy and motivation: What to do, what to say. Intervention in school and clinic, 41(4), 218-227.

Nakayama, M., \& Santiago, R. (2012). Learner characteristics and online learning. In Norbert M. Seel (Eds.), Encyclopedia of the sciences of learning (pp. 1745-1747). New York, NY: Springer.

O’Malley, J. M., \& Chamot, A. U. (1990). Learning strategies in second language acquisition. Cambridge, UK: Cambridge University Press.

Oxford, R. L. (1990). Language learning strategies: What every teacher should know. Boston, MA: Heinle \& Heinle Publishers. 
Pajares, F. (2003). Self-efficacy beliefs, motivation and achievement in writing. Reading and Writing Quarterly, 19(2), 139-158.

Pintrich, P., \& De Groot, E. (1990). Motivational and self-regulated learning, components of classroom academic performance. Journal of Educational Psychology, 82, 33-40.

Rababah, A. G., \& Bulut, D. (2007). Compensatory strategies in Arabic as a second language. Poznan Studies in Contemporary Linguistics, 43(2), 83-106.

Rahimi, A., \& Abedini, A. (2009). The interface between EFL learners' self- efficacy concerning listening comprehension and listening proficiency. Novitas Royal, 3(1), 14-28.

Raoofi, S., Hoon Tan, B., \& Heng Chan, S. (2012). Self-efficacy in second/foreign language learning contexts. English Language Teaching, 5(11), 60-73.

Ross, J. A., Hogaboam-Gray, A., \& Hannay, L. (2001). Effects of teacher efficacy on computer skills and computer cognitions of K-3 students. Elementary School Journal, 102, 141-156.

Schunk, D. H. (2003). Self-efficacy for reading and writing: Influence of modeling, goal setting and self-evaluation. Reading and Writing Quarterly: Overcoming Learning Difficulties, 19(2), 159-172.

Schunk, D. H. (1991). Self-efficacy and academic motivation. Educational Psychologist, 26(3), 207-231.

Taheri, A. A., \& Davoudi, M. (2016). The use of compensation strategies in the Iranian EFL learners' speaking and its relationship with their foreign language proficiency. Journal of Education and Practice, 7(9), 165-179.

Wenden, A., \& Rubin, J. (1987). Learner strategies in language learning. Englewood Cliffs, NY: Prentice/Hall International.

Yilmaz, C. (2010). The relationship between language learning strategies, gender, proficiency and self-efficacy beliefs: A study of ELT learners in Turkey. Procedia - Social and Behavioral Sciences, 2(2), 682-687.

Zimmerman, B. J., Bandura, A., \& Martinez-Pons, M. (1992). Self-motivation for academic attainment: The role of selfefficacy beliefs and personal goal setting. American Educational Journal, 29, 663-676. 